\title{
KAJIAN EFEK SPASIAL PADA KASUS DIFTERI DENGAN METODE GEOGRAPHICALLY WEIGHTED NEGATIVE BINOMIAL REGRESSION (GWNBR)*
}

\author{
Diva Arum Mustika ${ }^{1}$ and Rani Nooraeni ${ }^{2 \ddagger}$ \\ ${ }^{1}$ Politeknik Statistika STIS, Indonesia,14.8089@stis.ac.id \\ 2Politeknik Statistika STIS, Indonesia, raninoor@stis.ac.id \\ ‡corresponding author
}

\author{
Indonesian Journal of Statistics and Its Applications (elSSN:2599-0802) \\ Vol 3 No 1 (2019), 91 - 104
}

Copyright ( 2019 Diva Arum Mustika and Rani Nooraeni. This is an open-access article distributed under the Creative Commons Attribution License, which permits unrestricted use, distribution, and reproduction in any medium, provided the original work is properly cited.

\begin{abstract}
Diphtheria is an infectious disease caused by the Corynebacterium diphtheriae bacteria. Indonesia is the country with the most cases of diphtheria in Southeast Asia and ranks third in the world. In 2016, cases of diphtheria increased by 65 percent and became Extraordinary Events (KLB) in Indonesia, even though during 2013 to 2015 the number of cases of diphtheria has decreased. The province that has the highest number of diphtheria cases in Indonesia in 2016 is East Java. Diphtheria is centered and spread in certain districts / cities in East Java Province so that there are indications of spatial effects in the spread of diphtheria. Because data on the number of diphtheria cases overdispersed and indicated spatial effects in its spread, the main method used in this study was Geographically Weighted Negative Binomial Regression (GWNBR). This method will be compared with other alternative methods namely Poisson regression method and Negative Binomial Regression to get the best modeling. Based on the AIC value of each model it can be concluded that the best method for modeling the number of diphtheria cases is GWNBR. The modeling results with GWNBR show that there is indeed a spatial influence on the number of diphtheria cases and risk factors in East Java Province in 2016. The percentage of DPT-HB3 / DPT-HB-Hib3 immunization coverage is not significant in all observation areas, while the percentage of drug and vaccine availability is significant at entire observation.
\end{abstract}

Keywords: diphtheria, GWNBR, negative binomial, overdispersion, spatial.

\footnotetext{
"Received Nov 2018; Accepted Feb 2019; Published online on Feb 2019
} 


\section{Pendahuluan}

Difteri adalah penyakit yang berpotensi fatal dan menular yang biasanya melibatkan hidung, tenggorokan, dan saluran pernapasan tetapi juga dapat menginfeksi kulit. Penyakit difteri disebabkan oleh bakteri Corynebacterium diphtheriae yang menyerang sistem pernapasan bagian atas. Ciri yang paling mencolok adalah pembentukan membran keabu-abuan yang menutupi amandel dan bagian atas tenggorokan (Smith, 2008). Sumber penularan penyakit difteri adalah manusia, baik sebagai penderita maupun sebagai carrier atau pembawa. Penularan terjadi dari satu orang ke orang lain melalui pernapasan atau droplet infection secara kontak fisik yang berdekatan.

Saat ini penyakit difteri masih menjadi masalah beberapa negara di dunia. Berdasarkan data World Health Organization (WHO), pada tahun 2016 terdapat 7.097 kasus difteri yang dilaporkan di seluruh dunia. Negara dengan jumlah kasus difteri terbanyak yaitu India, Madagascar, dan Indonesia. Indonesia merupakan negara dengan kasus difteri terbanyak di Asia Tenggara dan ketiga di dunia. Kasus difteri di Indonesia pada tahun 2016 mengalami peningkatan sebesar 65\% dari 252 kasus menjadi 415 kasus dibandingkan dengan tahun sebelumya. Selain itu, distribusi penyakit difteri juga semakin meningkat dari 13 provinsi tahun 2015 kemudian meluas menjadi 20 provinsi pada tahun 2016.

Sejak tahun 2008, Provinsi Jawa Timur selalu menempati urutan pertama dengan jumlah kasus difteri terbanyak di Indonesia kecuali pada tahun 2015. Provinsi Jawa Timur kembali menjadi provinsi dengan jumlah kasus difteri terbanyak di Indonesia pada tahun 2016 dengan 348 kasus atau sekitar 84\% dari total kasus di Indonesia. Penyakit difteri merupakan kasus "re-emerging disease" karena kasus difteri sebenarnya sudah menurun di tahun 1985, namun kembali meningkat pada tahun 2005 saat terjadi Kejadian Luar Biasa (KLB) di Kabupaten Bangkalan dan hingga tahun 2016 jumlahnya terus meningkat dan menyebar di seluruh wilayah Provinsi Jawa Timur.

Berdasarkan skala pengukurannya, jumlah kasus dipteri dapat dimodelkan dengan metode regresi poisson dan binomial negatif. Regresi poisson dapat digunakan apabila varians dari variabel respon sama dengan nilai rata-ratanya atau equidispersi (Cameron \& Trivedi, 2013). Akan tetapi dalam kenyataannya asumsi tersebut sulit untuk dipenuhi. Varians dari variabel respon seringkali lebih besar dari rata-ratanya atau overdispersi. Salah satu pendekatan yang dapat digunakan untuk mengatasi masalah overdispersi yaitu dengan menggunakan regresi binomial negatif (McCullagh \& Nelder, 1989).

Dari penelitian-penelitian yang telah dilakukan sebelumnya, difteri merupakan penyakit menular yang sangat berkaitan dengan kondisi suatu wilayah. Di Provinsi Jawa Timur, penyakit difteri terpusat dan menyebar di kabupaten atau kota tertentu sehingga ada indikasi terdapat efek spasial dalam persebaran penyakit difteri. Oleh karena itu, penelitian ini akan menggunakan Geographically Weighted Negative Binomial Regression (GWNBR) dalam memodelkan jumlah kasus difteri di Provinsi Jawa Timur tahun 2016.

Berdasarkan uraian sebelumnya, merupakan hal penting untuk mengetahui bagaimana gambaran dan peta persebaran kasus difteri dan karakteristiknya di Provinsi Jawa Timur? Apakah terdapat efek spasial pada kasus penyebaran resiko difteri? Faktor apa saja yang berpengaruh signifikan terhadap peningkatan risiko jumlah kasus difteri? Metode apa yang dapat memodelkan jumlah kasus difteri lebih baik diantara ketiga metode yang diusulkan. 


\section{Tinjauan Pustaka}

Penyakit difteri merupakan penyakit yang sangat mudah menular dan berbahaya karena dapat menyebabkan kematian pada $5-10 \%$ penderita. Banyaknya jumlah kasus atau penderita difteri membuka peluang persebaran penyakit yang semakin besar dan meluas. Menurut Kementerian Kesehatan Republik Indonesia (Kemenkes RI), faktor resiko difteri yaitu: (1) Akumulasi kelompok rentan yang tidak mendapatkan imunisasi. Berdasarkan cakupan imunisasi difteri 10 tahun terakhir, tren cakupan imunisasi difteri selalu lebih dari $90 \%$ namun masih terdapat populasi bayi yang tidak mendapat imunisasi. (2) Kepadatan rumah yang lebih dari lima penghuni meningkatkan resiko terjadinya penularan. KLB difteri sering terjadi pada daerah dengan kepadatan penduduk tinggi.

Tiga faktor yang menjadi penyebab terjadinya penyakit difteri menurut Gordon (1950), yaitu: (1) Faktor penyebab (agent), adalah penyebab esensial yang harus ada, agen biasanya dapat berupa benda hidup atau mati, dalam hal ini agen tersebut merupakan bakteri Corynebacterium diphtheriae. Untuk dapat mencegah dan mengobati penularan penyakit yang disebabkan oleh bakteri ini, diperlukan ketersediaan obat dan vaksin yang memadai pada suatu wilayah. (2) Faktor penjamu (host), merupakan faktor manusia yang dapat memberikan tempat tinggal atau kehidupan untuk bakteri menular. Faktor dari manusia yang rentan tertular oleh penyakit difteri yaitu kondisi gizi yang buruk dan keadaan sosial ekonomi yang rendah. (3) Faktor lingkungan (environment), adalah segala sesuatu selain faktor penjamu, seperti suasana lingkungan yang ada di sekitar manusia yang dapat memperburuk persebaran terjadinya suatu penyakit. Dalam hal ini yaitu lingkungan rumah yang tidak sehat dan sanitasi yang tidak layak.

\section{Metodologi}

\subsection{Data dan Variabel Penelitian}

Unit analisis dalam penelitian ini mencakup 38 kabupaten/kota di Provinsi Jawa Timur. Variabel Penelitian yang digunakan dalam penelitian ini berasal dari sumber data sekunder berupa publikasi yang disusun oleh Dinas Kesehatan Provinsi Jawa Timur dan Badan Pusat Statistik. Berdasarkan tinjauan pustaka dan sumber data yang digunakan maka variable penelitian yang digunakan adalah sebagai berikut:

1. Variabel kepadatan penduduk $\left(x_{1}\right)$ dan persentase penduduk miskin $\left(x_{2}\right)$ untuk masing-masing kabupaten/kota di Provinsi Jawa Timur diperoleh dari Publikasi Provinsi Jawa Timur Dalam Angka tahun 2017 oleh Badan Pusat Statistik.

2. Variable yang dikumpulkan antara lain jumlah kasus difteri $(y)$, persentase cakupan imunisasi DPT-HB3 $\left(\mathrm{x}_{3}\right)$, jumlah kasus balita gizi buruk $\left(\mathrm{x}_{4}\right)$, persentase rumah sehat $\left(\mathrm{x}_{5}\right)$, persentase desa yang melaksanakan STBM $\left(\mathrm{x}_{6}\right)$, dan perentase ketersediaan obat dan vaksin $\left(x_{7}\right)$ untuk masing-masing kabupaten/kota di Provinsi Jawa Timur diperoleh dari Publikasi Profil Kesehatan Provinsi Jawa Timur tahun 2016 oleh Dinas Kesehatan Provinsi Jawa Timur.

3. Data pendukung yang digunakan adalah Shapefile peta yang memuat koordinat lokasi untuk setiap kabupaten/kota di Provinsi Jawa Timur diperoleh dari Badan Pusat Statistik.

\subsection{Metode Analisis}

Metode regresi poisson, regresi binomial negatif, dan Geographically Weighted Negative Binomial Regression (GWNBR) digunakan untuk memodelkan jumlah kasus difteri dengan variabel bebas yaitu kepadatan penduduk, persentase penduduk miskin, 
persentase cakupan imunisasi DPT-HB3/DPT-HB-Hib3, jumlah kasus balita gizi buruk, persentase rumah sehat, persentase desa yang melaksanakan STBM, serta persentase ketersediaan obat dan vaksin menggunakan Software yang digunakan untuk melakukan analisis ini yaitu GeoDa 1.10.0.2 dan $R$ Studio 3.4.0.

\section{Regresi Poisson}

Distribusi poisson merupakan model distribusi untuk data count non- negatif. Probabilitas distribusi Poisson bergantung pada parameter tunggal yaitu mean $(\mu)$. Fungsi kepadatan peluang dari distribusi poisson adalah sebagai berikut (Hilbe, 2011):

$$
f(y ; \mu)=\frac{e^{-\mu} \mu^{y}}{y !}, \quad y=0,1,2, \ldots .
$$

Dalam regresi poisson yang melibatkan $n$ pasangan data, variabel respon $(\mathrm{Yi})$ dan variabel penjelas $(\mathrm{Xi})$ dengan $\mathrm{i}=1,2,3, \ldots, \mathrm{n}$ memiliki hubungan antarvariabel. Hubungan tersebut dinyatakan sebagai berikut:

$$
Y_{i}=\mu_{i}+\varepsilon_{i}
$$

Komponen acak adalah variable respon (Yi) yang berdistribusi poisson,

$$
Y_{i} \sim \text { Poisson }\left[\exp \left(\sum_{j=0}^{p} \beta_{j} x_{i j}\right)\right]
$$

dan komponen link function $\eta$ sebagai berikut:

$$
\eta_{i}=\ln \left(\mu_{i}\right)=\boldsymbol{x}_{i}^{T} \boldsymbol{\beta}
$$

Berdasarkan persamaan (2) dan (4). Maka estimasi model Poisson berdasarkan parameterisasi log-likelihood dari distribusi Poisson, yang bertujuan untuk menduga nilai parameter dapat menggunakan metode Maximum Likelihood Estimation (MLE). Fungsi likelihood dari model regresi poisson adalah sebagai berikut:

$$
L\left(\beta ; y_{i}\right)=\prod_{i=1}^{n} \exp \left[y_{i}\left(\boldsymbol{x}_{i}^{T} \boldsymbol{\beta}\right)-e^{\boldsymbol{x}_{i}^{T} \boldsymbol{\beta}}-\ln (y !)\right]
$$

dan logaritma natural dari fungsi likelihood adalah:

$$
\ln L\left(\beta, y_{i}\right)=\sum_{i=1}^{n}\left[y_{i}\left(\boldsymbol{x}_{i}^{T} \boldsymbol{\beta}\right)-\exp \left(\boldsymbol{x}_{i}^{T} \boldsymbol{\beta}\right)-\ln \left(y_{i} !\right)\right]
$$

\section{Overdispersi}

Ciri utama pada regresi poisson yaitu nilai rata-rata pada variabel respon memiliki nilai yang sama dengan variansnya atau lebih dikenal dengan equidispersi. Dalam prakteknya, observasi yang berupa data count seringkali menunjukkan variabilitas yang melebihi nilai rata-rata. Kondisi ini disebut dengan overdispersi.

Indikasi ada atau tidaknya overdispersi pada data dapat diketahui dengan melihat rasio varians terhadap rata-ratanya atau dapat menggunakan Pearson Chi-square dibagi dengan derajat bebasnya (persamaan 7). Apabila nilai rasio tersebut lebih besar dari 1, maka hal ini mengindikasikan adanya overdispersi pada data.

$$
\chi^{2}=\sum_{i=1}^{n} \frac{\left(y_{i}-E(Y)\right)^{2}}{\operatorname{var}(Y)} ; \theta=\frac{\chi^{2}}{n-k}
$$




\section{Regresi Binomial Negatif}

Regresi binomial negatif merupakan model alternatif untuk mengatasi masalah overdispersi pada regresi poisson. Regresi binomial negatif melibatkan suatu parameter dispersi sehingga nilai varians data sampel dapat lebih besar dari nilai rataratanya. Distribusi binomial negatif merupakan gabungan dari distribusi poisson dan distribusi gamma sehingga menghasilkan fungsi kepadatan peluang binomial negative sebagai berikut:

$$
f(y ; \mu ; \theta)=\frac{\Gamma\left(y+\frac{1}{\theta}\right)}{\Gamma\left(\frac{1}{\theta}\right) \Gamma(y+1)}\left(\frac{\frac{1}{\theta}}{\mu+\frac{1}{\theta}}\right)^{\frac{1}{\theta}}\left(1-\frac{\frac{1}{\theta}}{\mu+\frac{1}{\theta}}\right)^{y}, y=0,1,2, \ldots .
$$

Dimana $\mu$ dan $\theta$ adalah parameter dari distribusi binomial negatif. Pada distribusi binomial negatif memiliki rata-rata dan varians masing-masing $E(Y)=\mu$ dan $\operatorname{var}(Y)=$ $\mu+\theta \mu^{2}$. $\theta$ adalah parameter dispersi, dimana jika $\theta=0$ maka distribusi binomial negatif memiliki varians sama dengan rata-rata seperti distribusi poisson. Apabila $\theta>0$ maka variansnya lebih besar daripada varians distribusi poisson sehingga model binomial negatif terlihat dapat mengatasi data count yang terindikasi kasus overdispersi. Dengan menggunakan metode Maximum Likelihood Estimation (MLE), pendugaan parameter regresi binomial negatif dapat dilakukan

$$
\begin{aligned}
\ln L\left(\beta ; y_{i} ; \theta\right)= & \sum_{i=1}^{n}\left\{y_{i} \ln \left(\frac{\theta \exp \left(\boldsymbol{x}_{i}^{T} \boldsymbol{\beta}\right)}{1+\theta \exp \left(\boldsymbol{x}_{i}^{T} \boldsymbol{\beta}\right)}\right)-\left(\frac{1}{\theta}\right) \ln \left(1+\theta \exp \left(\boldsymbol{x}_{i}^{T} \boldsymbol{\beta}\right)\right)+\ln \Gamma\left(y_{i}+\right.\right. \\
& \left.\left.\frac{1}{\theta}\right)-\ln \Gamma\left(y_{i}+1\right)-\ln \Gamma\left(\frac{1}{\theta}\right)\right\}
\end{aligned}
$$

\section{Spasial dependency}

Hukum Tobler I menyatakan bahwa segala sesuatu saling terkait namun sesuatu yang lebih dekat memiliki keterkaitan yang lebih besar. Kejadian ini kemudian menghasilkan isu mengenai autokorelasi spasial. Ukuran keterkaitan (dependensi) spasial yang sering digunakan yaitu indeks Moran's I dan moran scatterplot.

$\mathrm{H}_{0}: \mathrm{I}=0$ (tidak terdapat dependensi spasial)

$\mathrm{H}_{1}: I \neq 0$ (terdapat dependensi spasial)

Statistik uji :

dimana:

$$
Z=\frac{I-E(I)}{\sqrt{\operatorname{var}(I)}} \sim N(0,1)
$$

$E(I)=-\frac{1}{n-1}$

$\operatorname{var}(I)=\frac{n^{2} S_{1}-n S_{2}+3 S_{0}^{2}}{\left(n^{2}-1\right) S_{0}^{2}}-[E(I)]^{2}$

$S_{0}=\sum_{i=1}^{n} \sum_{j=1}^{n} w_{i j} ; S_{1}=\frac{1}{2} \sum_{i=1}^{n} \sum_{j=1}^{n}\left(w_{i j}+w_{j i}\right)^{2} ; S_{2}=\sum_{i=1}^{n}\left(w_{i} .+w_{. i}\right)^{2}$

Dengan tingkat signifikansi $\alpha$, tolak hipotesis nol apabila $Z_{\text {hit }}>Z_{\alpha / 2}$ atau $Z_{\text {hit }}<Z_{\alpha / 2}$, dengan demikian terdapat dependensi spasial pada atribut yang diamati. 


\section{Spasial Heterogenitas}

Salah satu asumsi yang harus dipenuhi dalam pemodelan spasial adalah asumsi heteroskedastisitas. Heteroskedastisitas adalah keadaan dimana error pada model memiliki ragam yang tidak konstan dan kovarian error tidak sama dengan nol. Salah satu alat yang digunakan untuk meguji apakah sebuah model bersifat heteroskedastis adalah uji statistik Breusch-Pagan. Breusch-Pagan sebanding dengan distribusi chisquare dengan derajat bebas $p-1$, dimana $p$ adalah banyaknya parameter dalam model. Pengujian heterogenitas spasial bertujuan untuk melihat perbedaan karakteristik wilayah observasi.

Hipotesis dan statistik uji Breusch-Pagan adalah sebagai berikut:

$\mathrm{H}_{0}: \sigma_{1}{ }^{2}=\sigma_{2}{ }^{2}=\cdots=\sigma^{2}$

$\mathrm{H}_{1}$ : minimal terdapat satu $\sigma_{i}^{2} \neq \sigma^{2}$

Statistik uji:

$$
B P=\frac{1}{2} \boldsymbol{f}^{T} \boldsymbol{A}\left(\boldsymbol{A}^{T} \boldsymbol{A}\right)^{-1} \boldsymbol{f} \sim \chi_{p-1}^{2}
$$

dimana:

$f_{i}=\frac{e_{i}^{2}}{\sigma^{2}}-1$

$e_{i}$ : error dari observasi ke- $i$

A : matriks dari vektor terstandardisasi untuk tiap nilai observasi

Dengan tingkat signifikansi $\alpha$, hipotesis nol ditolak dilakukan apabila nilai $B P>$ $\chi_{(\alpha, p-1)}^{2}$. Apabila hipotesis nol ditolak artinya data wilayah observasi mengalami heterogenitas spasial.

\section{Matriks Penimbang Spasial}

Dalam mengatasi masalah heterogenitas spasial, digunakan penimbang untuk setiap lokasi (wilayah yang diteliti). Terdapat beberapa jenis penimbang yang dapat digunakan, salah satunya dengan menggunakan fungsi kernel. Fungsi kernel yang biasa digunakan yaitu Fungsi Kernel Gaussian dan Fungsi Kernel Bisquare. Fotheringham (2002) mendefinisikan kedua kernel tersebut sebagai berikut:

a. Fungsi Kernel Gaussian

$$
w_{i j}=\exp \left[-\frac{1}{2}\left(\frac{d_{i j}}{b}\right)^{2}\right]
$$

b. Fungsi Kernel Bisquare

dimana:

$$
w_{i j}=\left\{\begin{array}{cc}
{\left[1-\left(\frac{d_{i j}}{b}\right)^{2}\right]^{2},} & \text { jika } d_{i j}<b \\
0 & \text { lainnya }
\end{array}\right.
$$

$w_{i j}$ : penimbang spasial

$d_{i j}$ : jarak euclidian anatara wilayah ke-i dan ke-j

$b$ : parameter nonnegatif (bandwidth)

$$
d_{i j}=\sqrt{\left(u_{i}-u_{j}\right)^{2}+\left(v_{i}-v_{j}\right)^{2}}
$$




\section{Geographically Weighted Negative Binomial Regression GWNBR}

Geographically Weighted Negative Binomial Regression (GWNBR) merupakan suatu metode statistik perluasan dari metode Geographically Weighted Regression (GWR) untuk menduga parameter lokal dengan unit amatan berupa wilayah pada data count yang memiliki heterogenitas spasial dan mengalami overdispersi. Dengan metode GWNBR akan diperoleh penduga paramater yang sifatnya lokal pada setiap wilayah. Model GWNBR dapat dituliskan sebagai berikut:

$$
E\left(Y_{i}\right)=\mu_{i}=\exp \left\{\beta_{0}\left(u_{i}, v_{i}\right)+\sum_{k=1}^{p} \beta_{k}\left(u_{i}, v_{i}\right) x_{i k}+\theta\left(u_{i}, v_{i}\right)\right\},
$$

dimana:

$y_{i} \quad$ : nilai observasi variabel respon ke- $i$

$x_{i k} \quad$ : nilai observasi variabel prediktor ke-k pada amatan lokasi $\left(u_{i}, v_{i}\right)$

$\beta_{k}\left(u_{i}, v_{i}\right)$ : koefisien regresi variabel prediktor ke- $k$ untuk setiap lokasi $\left(u_{i}, v_{i}\right)$

$\theta\left(u_{i}, v_{i}\right)$ : parameter dispersi untuk setiap lokasi $\left(u_{i}, v_{i}\right)$

$u_{i} \quad:$ koordinat latitude titik amatan ke- $i$

$v_{i} \quad:$ koordinat longitude titik amatan ke- $i$

Penggunaan pembobot spasial dalam GWNBR menyebabkan fungsi log-likelihood pada model menjadi:

$$
\begin{aligned}
\ln L\left(\boldsymbol{\beta}\left(u_{i}, v_{i}\right), \theta_{i} \mid y_{i}, x_{i}\right)= & \sum_{i=1}^{n} w_{i j}\left(u_{i}, v_{i}\right)\left[y_{i} \ln \left(\frac{\theta \mu_{i}}{1+\theta \mu_{i}}\right)-\frac{1}{\theta} \ln \left(1+\theta \mu_{i}\right)+\ln \Gamma\left(y_{i}+\frac{1}{\theta}\right)-\overline{13}\right) \\
& \left.\ln \Gamma\left(y_{i}+1\right)-\ln \Gamma\left(\frac{1}{\theta}\right)\right]
\end{aligned}
$$

Pendugaan parameter koefisien regresi dilakukan dengan metode MLE dengan memaksimalkan fungsi log-likelihood pada persamaan di atas. Parameter koefisien yang akan diperoleh adalah koefisien variabel prediktor $\left(\beta_{j}\left(u_{i}, v_{i}\right)\right)$ dan parameter dispersi $\left(\theta_{i}\left(u_{i}, v_{i}\right)\right)$ dengan menggunakan metode iterasi Newton-Raphson.

\section{Pengujian Simultan Parameter Regresi Model GWNBR}

Pengujian simultan parameter regresi model GWNBR bertujuan untk mengetahui apakah variabel-variabel penjelas secara bersama-sama berpengaruh secara signifikan terhadap variabel respon. Hipotesis pengujian simultan yang digunakan adalah:

$\mathrm{H}_{0}: \beta_{1 i}=\beta_{2 i}=\beta_{3 i}=\cdots=\beta_{k i}=0$

$\mathrm{H}_{1}$ : minimal ada satu $\beta_{j i} \neq 0$, untuk $j=1,2, \ldots, k$

Statistik uji:

$$
G=-2 \ln \left[\frac{L(\widehat{\omega})}{L(\widehat{\Omega})}\right] \sim \chi_{(k)}^{2}
$$

Dengan $L(\widehat{\omega})$ merupakan besar likelihood untuk himpunan parameter di bawah $\mathrm{H}_{0}$ (intercept only) sementara $L(\widehat{\Omega})$ merupakan besar likelihood pada model dengan seluruh variabel prediktor. Dengan tingkat signifikansi a, hipotesis nol akan ditolak apabila nilai $G>\chi_{(\alpha, k)}^{2}$ yang artinya terdapat satu variabel prediktor yang berpengaruh signifikan terhadap variabel respon. 


\section{Pengujian Parsial Parameter Regresi Model GWNBR}

Pengujian secara parsial parameter regresi model GWNBR dilakukan untuk mengetahui apakah variabel prediktor secara parsial memengaruhi variabel respon pada setiap wilayah observasi. Hipotesis pengujian parsial yang digunakan adalah:

$\mathrm{H}_{0}: \beta_{j}\left(u_{i}, v_{i}\right)=0$

$\mathrm{H}_{0}: \beta_{j}\left(u_{i}, v_{i}\right) \neq 0$, untuk $j=1,2, \ldots, k$

Statistik uji:

$$
Z=\frac{\hat{\beta}_{j}\left(u_{i}, v_{i}\right)}{\operatorname{se}\left(\hat{\beta}_{j}\left(u_{i}, v_{i}\right)\right)} \sim N(0,1)
$$

Dengan tingkat signifikansi $\alpha$, hipotesis nol ditolak apabila nilai $\left|Z_{h i t}\right|>Z_{\alpha / 2}$ yang artinya terdapat pengaruh yang signifikan dari variabel prediktor ke-j pada wilayah observasi $\left(u_{i}, v_{i}\right)$.

\section{Evaluasi model GWNBR}

Evaluasi model dilakukan dengan cara membandingkan nilai Akaike Information Criterion (AIC). Model terbaik merupakan model yang memiliki nilai AIC terkecil. Gill (2001) menuliskan formula AIC sebagai berikut:

dimana:

$$
A I C=-2 l(\hat{\theta} \mid y)+2 p
$$

$l(\hat{\theta} \mid y)$ : nilai maksimum log-likelihood

$$
p \quad \text { : banyaknya parameter }(p=k+1)
$$

\section{Hasil dan Pembahasan}

\subsection{Sebaran Jumlah Kasus Difteri di Provinsi Jawa Timur Tahun 2016}

Jumlah kasus difteri dikelompokkan menjadi tiga kelompok yaitu rendah, sedang, dan tinggi (Gambar 1). Hanya satu kabupaten/kota yang memiliki kasus difteri dengan status kategori tinggi yaitu Kabupaten Blitar. Sementara wilayah yang memiliki status kategori sedang terdapat 6 kabupaten/kota, 4 diantaranya mengelompok di sebelah utara daratan Jawa Timur. Wilayah tersebut yaitu Kabupaten Gresik, Kota Surabaya, Kabupaten Sidoarjo, dan Kabupaten Pasuruan. Dua kabupaten/kota yang lain yaitu Kota Blitar dan Kota Malang. Untuk kasus difteri dengan status kategori rendah tersebar di bagian barat dan timur daratan Jawa Timur serta seluruh kabupaten/kota yang menduduki Pulau Madura.

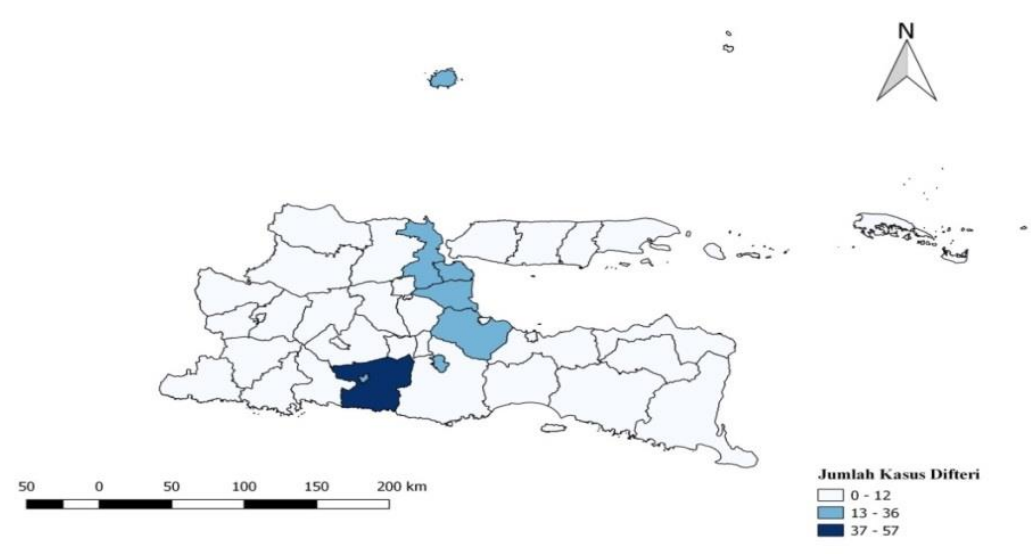

Gambar 1: Sebaran Jumlah Kasus Difteri menurut kabupaten/kota di Provinsi Jawa Timur tahun 2016. 


\subsection{Pemodelan Jumlah Kasus Difteri di Provinsi Jawa Timur Tahun 2016 dengan Metode GWNBR}

\section{Pemeriksaan Asumsi}

Sebelum melakukan pemodelan dilakukan pengecekan beberapa asumsi. Pengecekan yang pertama adalah asumsi multikolinieritas. Hasil pemeriksaan multikolinieritas menununjukkan bahwa tidak terdapat variabel yang memiliki nilai VIF lebih dari 10. Hal tersebut menunjukkan bahwa tidak terdapat hubungan linier yang berarti antar variabel independen sehingga asumsi non-multikolinieritas terpenuhi dan ketujuh variabel independen tersebut dapat digunakan dalam analisis.

Metode pertama yang digunakan dalam menganalisis jumlah kasus difteri adalah regresi poisson. Tabel 1. menunjukkan hasil dari pemodelan regresi Poisson. Diantara ketujuh variabel independen, terdapat empat variabel yang signifikan pada tingkat signifikansi 0.05 , variable tersebut adalah persentase penduduk miskin, persentase rumah sehat, persentase desa yang melaksanakan STBM, dan persentase ketersediaan obat dan vaksin.

Tabel 1: Pemodelan dengan Regresi Poisson

\begin{tabular}{|c|c|c|}
\hline Variabel & Estimasi & $p$-value \\
\hline Intercept & $8.48 \mathrm{E}+00$ & $<2 \mathrm{e}-16$ \\
\hline Kepadatan Penduduk $\left(\mathrm{x}_{1}\right)$ & $3,17 e-05$ & 0,338 \\
\hline Persentase Penduduk Miskin $\left(\mathrm{x}_{2}\right)$ & $-1,15 e-01$ & $2,76 \mathrm{e}-08$ * \\
\hline $\begin{array}{l}\text { Persentase Cakupan Imunisasi DPT/HB3 } \\
\left(\mathrm{x}_{3}\right)\end{array}$ & $-2,31 e-04$ & 0,9063 \\
\hline Jumlah Kasus Balita Gizi Buruk (x4) & $1,15 e-04$ & 0,7966 \\
\hline Persentase Rumah Sehat $\left(x_{5}\right)$ & $-1,15 \mathrm{e}-02$ & 0,0112 * \\
\hline $\begin{array}{l}\text { Persentase Desa yang Melaksanakan } \\
\text { STBM }\left(\mathrm{x}_{6}\right)\end{array}$ & $-1,56 e-02$ & $1,17 \mathrm{e}-14$ * \\
\hline $\begin{array}{l}\text { Persentase Ketersediaan Obat dan } \\
\text { Vaksin }\left(x_{7}\right)\end{array}$ & $-3,72 e-02$ & $6,23 e-09$ * \\
\hline
\end{tabular}

Pengecekan overdispersi dilakukan untuk menentukan apakah metode analisis dengan regresi Poisson dapat digunakan atau tidak. Hasil dari pengujian overdispersi menunjukkan bahwa dengan tingkat signifikansi 5 persen diperoleh $p$-value sebesar 5,11e-04 dengan parameter dispersi sebesar 7,638, artinya terdapat overdispersi pada jumlah kasus difteri sehingga regresi Poisson tidak tepat digunakan untuk kasus penelitian ini.

Metode kedua yang digunakan untuk memodelkan jumlah kasus difteri yang mengalami overdispersi yaitu regresi binomial negatif. Hasil pemodelannya menunjukkan bahwa dengan tingkat signifikansi 0.05 hanya terdapat satu variabel yang memengaruhi jumlah kasus difteri yaitu persentase desa yang melaksanakan STBM (Tabel 2).

Hasil pengujian dependensi spasial menunjukkan bahwa indeks Moran's untuk jumlah kasus difteri adalah 0,292 yang mengindikasikan adanya korelasi positif antar 
wilayah kabupaten. Selain itu, Moran's scatterplot (Gambar 2) menunjukkan adanya pengelompokkan pada kuadran III (low-low). Hal tersebut menunujukkan bahwa wilayah dengan jumlah kasus difteri yang rendah dikelilingi oleh wilayah dengan jumlah kasus difteri yang rendah juga. nilai $Z_{\text {hit }}$ sebesar 2,6935 dengan p-value 0,018 menunjukkan adanya dependensi spasial antar wilayah kabupaten. Nilai statistik Breush-Pagan sebesar 14,745 dengan p-value 0,039 menunjukkan bahwa terdapat heterogenitas spasial antar wilayah observasi.

Tabel 2: Pemodelan dengan Regresi Binomial Negatif

\begin{tabular}{|c|c|c|}
\hline Variabel & Estimasi & $p$-value \\
\hline Intercept & $8.954 \mathrm{e}+00$ & 0.000628 \\
\hline Kepadatan Penduduk ( $\left.\mathrm{x}_{1}\right)$ & $8.326 \mathrm{e}-05$ & 0.420131 \\
\hline Persentase Penduduk Miskin ( $\mathrm{x}_{2}$ ) & $-9.461 e-02$ & 0.074685 \\
\hline $\begin{array}{l}\text { Persentase Cakupan Imunisasi } \\
\left.\text { DPT/HB3 ( } x_{3}\right)\end{array}$ & $-1.273 e-03$ & 0.835882 \\
\hline Jumlah Kasus Balita Gizi Buruk (x4) & $-4.393 e-04$ & 0.729560 \\
\hline Persentase Rumah Sehat (x5) & $-1.242 e-02$ & 0.273724 \\
\hline $\begin{array}{l}\text { Persentase Desa yang Melaksanakan } \\
\text { STBM }\left(x_{6}\right)\end{array}$ & $-1.891 e-02$ & $\underset{*}{0.005417}$ \\
\hline $\begin{array}{l}\text { Persentase Ketersediaan Obat dan } \\
\text { Vaksin }\left(x_{7}\right)\end{array}$ & $-4.097 e-02$ & 0.054681 \\
\hline
\end{tabular}

Sumber: Output $R$

Ket: * signfikan pada tingkat signifikansi 5 persen

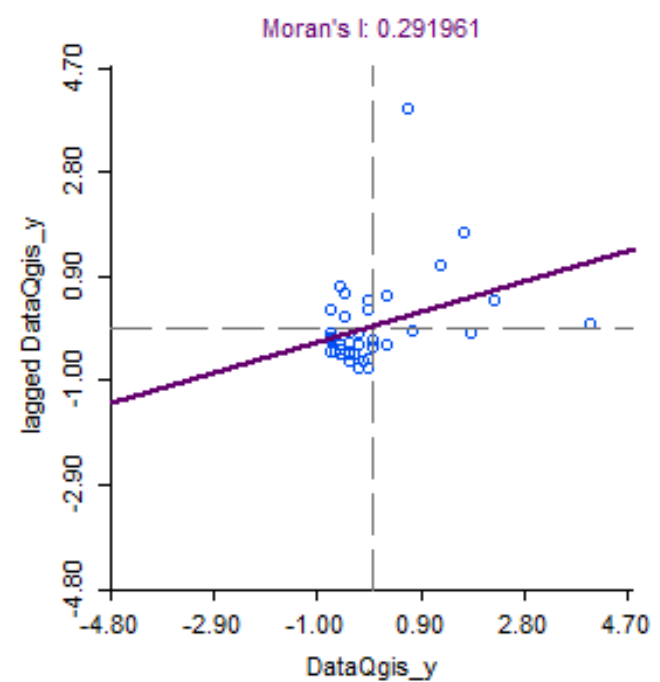

Gambar 2: Moran's Scatterplot

\section{Pemodelan Jumlah Kasus Difteri Menggunakan GWNBR}

Oleh karena jumlah kasus dipteri mengalami overdispersi dan dependensi spasial maka selanjutnya akan diterapkan metode GWNBR untuk memodelkan jumlah kasus difteri. Tahapan pertama adalah menghitung matriks penimbang spasial yang 
ditentukan menggunakan matriks jarak dan bandwidth optimum. Hasilnya, bandwidth yang terpilih yaitu sebesar 3,531675.

Model GWNBR menghasilkan 38 persamaan sesuai dengan jumlah kabupaten/kota di Provinsi Jawa Timur. Masing-masing Besaran koefisien parameter untuk masing masing kabupaten/kota bervariasi. Ringkasan koefisien parameter untuk setiap wilayah dapat dilihat pada Tabel 3.

Tabel 3: Ringkasan Parameter Koefisien GWNBR

\begin{tabular}{lrrrr}
\hline \multicolumn{1}{c}{ Variabel } & \multicolumn{1}{c}{ Mean } & \multicolumn{1}{c}{ Min } & \multicolumn{1}{c}{ Median } & \multicolumn{1}{c}{ Max } \\
\hline Theta & 0,3967 & 0,02993 & 0,39575 & 154,682 \\
Intercept & 8,945 & 8,894 & 8,935 & 9,303 \\
Kepadatan Penduduk $\left(x_{1}\right)$ & $7,41 \mathrm{e}-05$ & $3,86 \mathrm{e}-08$ & $7,08 \mathrm{e}-05$ & $2,36 \mathrm{e}-04$ \\
Persentase Penduduk Miskin $\left(\mathrm{x}_{2}\right)$ & $-0,10802$ & $-0,16029$ & $-0,10337$ & $-0,08292$ \\
Persentase Cakupan Imunisasi & $-1,81 \mathrm{e}-04$ & $-1,97 \mathrm{e}-03$ & $-3,69 \mathrm{e}-04$ & $9,03 \mathrm{e}-03$ \\
DPT/HB3 ( $\mathrm{x}_{3}$ ) & $1,50 \mathrm{e}-04$ & $-1,06 \mathrm{e}-03$ & $5,60 \mathrm{e}-05$ & $2,64 \mathrm{e}-03$ \\
Jumlah Kasus Balita Gizi Buruk $\left(\mathrm{x}_{4}\right)$ & $-1,37 \mathrm{e}-02$ & $-0,02432$ & $-0,013626$ & $-0,009443$ \\
Persentase Rumah Sehat $\left(\mathrm{x}_{5}\right)$ & $-0,01902$ & $-0,03619$ & $-0,0183$ & $-0,01509$ \\
Persentase Desa yang & & & $-0,04012$ & $-0,03552$ \\
Melaksanakan STBM $\left(\mathrm{x}_{6}\right)$ & $-0,03996$ & $-0,04664$ & $-0,0$ &
\end{tabular}

Sumber: Output $R$

Pengujian koefisien pada model GWNBR dilakukan secara simultan dan parsial. Pengujian secara simultan dapat dilihat berdasarkan nilai deviansnya. Nilai devians dari model GWNBR adalah 1.949,06 lebih besar dari nilai $\chi_{(7 ; 0,05)}^{2}=14,07$. Dengan demikian dapat disimpulkan bahwa pada tingkat signifikansi 0.05 terdapat minimal satu parameter signifikan dalam model.

Hasil pengujian parsial pada tingkat signifikansi 0.05 menunjukkan bahwa tidak seluruh parameter lokal berpengaruh secara signifikan di dalam model GWNBR. Contohnya dalam persamaan yang terbentuk untuk Kabupaten Blitar (No. Kabupaten/kota: 3505$)$ adalah sebagai berikut:

$$
\begin{aligned}
\hat{\mu}_{3505}= & \exp \left(8,931+0,0000698 x_{1}-0,10856^{*} x_{2}-0,00173 x_{3}+\right. \\
& \left.0,0000355 x_{4}-0,01333^{*} x_{5}-0,01812^{*} x_{6}-0,03868^{*} x_{7}\right)
\end{aligned}
$$

Ket: * signfikan pada tingkat signifikansi 0.05

Berdasarkan persamaan tersebut menunjukkan bahwa dengan tingkat signifikansi 0.05 terdapat 4 variabel bebas yang signifikan memengaruhi jumlah kasus difteri di Kabupaten Blitar. Keempat variable tersebut yaitu persentase penduduk miskin ( $\left.\mathrm{x}_{2}\right)$, persentase rumah sehat $\left(\mathrm{x}_{5}\right)$, persentase desa yang melaksanakan STBM $\left(\mathrm{x}_{6}\right)$, dan persentase ketersediaan obat dan vaksin $\left(\mathrm{x}_{7}\right)$.

\section{Pengelompokkan Wilayah Berdasarkan Variabel yang Signifikan}

Pemodelan dengan menggunakan metode GWNBR menghasilkan koefisien parameter lokal yang berbeda-beda antar observasi begitu pula dengan nilai $Z_{\text {hitung }}$ untuk masing-masing observasi. Hal tersebut memungkinkan suatu variabel signifikan berpengaruh pada wilayah tertentu namun tidak signifikan pada wilayah yang lain, dan sebaliknya. Oleh karena itu, pengelompokkan wilayah berdasarkan variabel yang 
signifikan perlu dilakukan untuk mengidentifikasi wilayah dengan karakteristik yang sama.

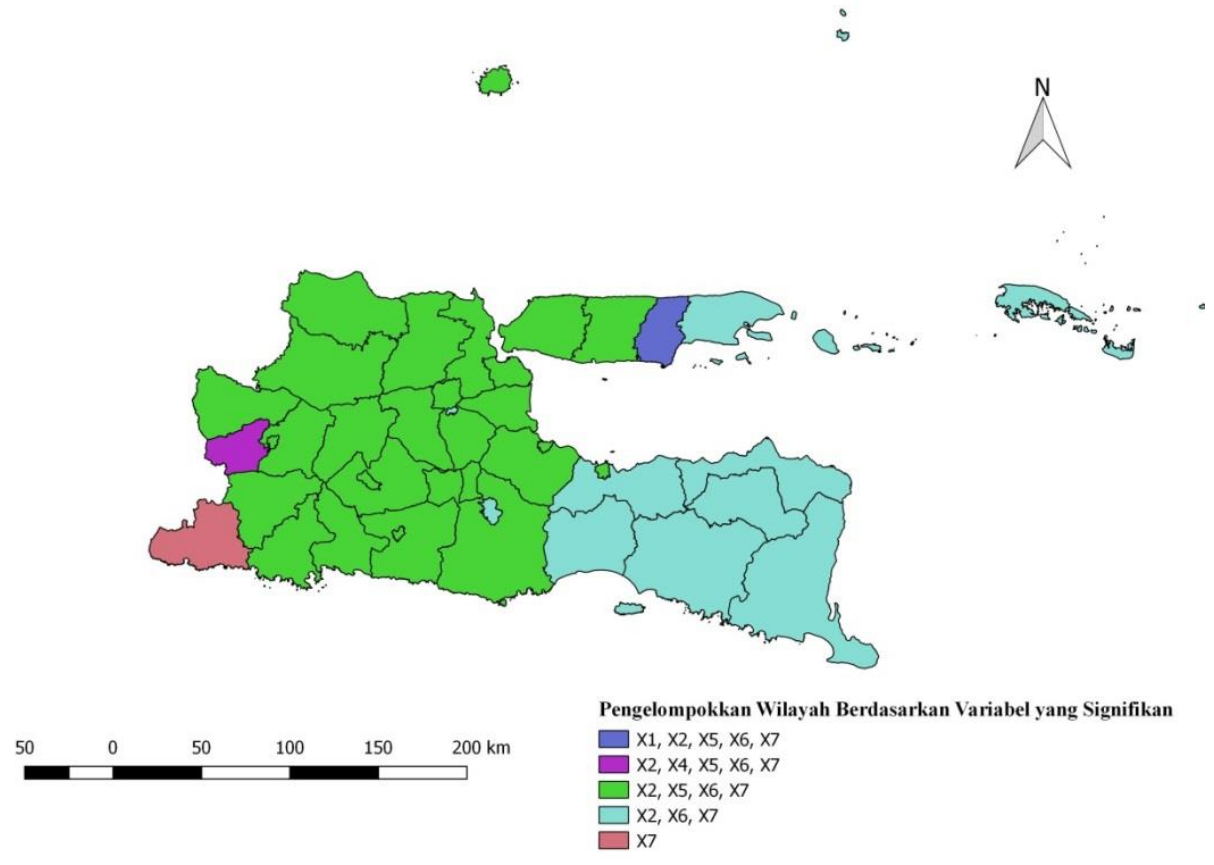

Gambar 3: Pengelompokkan Wilayah Berdasarkan Variabel yang Signifikan.

Berdasarkan variable yang signifikan pada masing-masing kabupaten, maka metode GWNBR berhasil mengelompokkan 38 kabupaten/kota di Provinsi Jawa Timur menjadi 5 kelompok. Pada Gambar 3 terlihat bahwa wilayah kabupaten/kota yang berdekatan cenderung memiliki variabel signifikan yang sama. Hal tersebut mengindikasikan adanya dependensi spasial antar wilayah observasi.

\section{Evaluasi Model GWNBR}

Pemodelan Jumlah kasus difteri telah dilakukan dengan menggunakan metode regresi poisson, regresi binomial negatif, dan Geographically Weighted Negative Binomial Regression. Untuk menentukan model mana yang lebih baik dalam menganalisis jumlah kasus difteri dilakukan evaluasi model berdasarkan nilai AIC yang dihasilkan masing-masing model.

Tabel 4: Perbandingan Nilai AIC Model Regresi Poisson, Regresi Binomial Negatif, dan GWNBR

\begin{tabular}{lc}
\hline \multicolumn{1}{c}{ Model Regresi } & AIC \\
\hline Regresi Poisson & 429,62 \\
Regresi Binomial Negatif & 250,75 \\
GWNBR & 193,3178 \\
\hline
\end{tabular}

Sumber: Output $R$

Tabel 4 menunjukkan bahwa model GWNBR memiliki nilai AIC yang lebih kecil dibandingkan dengan regresi poisson dan regresi binomial Negatif. Artinya, model GWNBR lebih baik dalam memodelkan jumlah kasus difteri di Provinsi Jawa Timur dibandingkan dengan regresi poisson dan regresi binomial negatif. 


\section{Kesimpulan}

Jumlah kasus difteri di Provinsi Jawa Timur tahun 2016 tersebar cukup bervariasi di seluruh provinsi dan cenderung berkelompok. Terdapat efek spasial pada kasus dipteri di Propinsi Jawa Timur, terbukti dengan hasil uji dependensi dan heterogenitas spasial yang menunjukkan hasil yang signifikan. Artinya terdapat keterkaitan dan keragaman spasial antar kabupaten/kota di Provinsi Jawa Timur terkait dengan penularan penyakit difteri.

Hasil evaluasi model regresi poisson, regresi binomial negatif, dan Geographically Weighted Negative Binomial Regression (GWNBR) menunjukkan bahwa metode GWNBR lebih baik dalam memodelkan jumlah kasus difteri di Provinsi Jawa Timur tahun 2016.

Berdasarkan model GWNBR, pada tingkat signifikansi 5 persen didapatkan faktorfaktor yang signifikan secara statistik memengaruhi jumlah kasus difteri adalah bervariasi antar kabupaten/kota di Provinsi Jawa Timur. Persentase cakupan imunisasi DPT-HB3/DPT-HB-Hib3 tidak signifikan di seluruh wilayah observasi, sedangkan persentase ketersediaan obat dan vaksin signifikan pada seluruh wilayah observasi.

\section{Daftar Pustaka}

Achmadi, U.F. (2014). Manajemen Penyakit Berbasis Wilayah Ed. Revisi. Jakatra: Rajawali Press.

Bustaman, U., Sofa, W.A., Larasati, D.N., Sari, A.K., Yuniarti, Hidayah, A., Oktaviana, S., Andriani, V.R. \& Saryono. (2013). Penggunaan Metode Geographically Weighted Regression (GWR) untuk Analisis Data Sosial dan Ekonomi. Jakarta: Badan Pusat Statistik.

Badan Pusat Statistik Provinsi Jawa Timur. (2017). Provinsi Jawa Timur Dalam Angka Tahun 2017. Surabaya: Badan Pusat Statistik Provinsi Jawa Timur.

Cameron, A., \& Trivedi, P. (2013). Regression Analysis of Count Data (2nd ed). Cambridge: Cambridge University Press.

Da Silva, A.R. \& Rodrigues, T.C.V. (2013). Geographically Weighted Negative Binomial Regression-incorporating overdispersion. New York: Springer.

Dinas Kesehatan Provinsi Jawa Timur. (2017). Profil Kesehatan Provinsi Jawa Timur 2016. Surabaya: Dinkes, Jatim.

Fotheringham, A.S., Brunsdon, C. \& Charlton, M. (2002). Geographically Weighted Regression (The Analysis of Spatially Varying Relationships). Chichester: John Wiley \& Sons, Ltd.

Hilbe, J. (2011). Negative Binomial Regression (2 ${ }^{\text {nd }}$ ed). New York: Cambridge University Press

Kartono, B. (2008). Lingkungan Rumah dan Kejadian Difteri di Kabupaten Tasikmalaya dan Kabupaten Garut. Jurnal Kesehatan Masyarakat Nasional, Vol. 2, No. 5.

Kementerian Kesehatan Republik Indonesia. (2012). Profil Kesehatan Indonesia 
2011. Jakarta: Kemenkes, RI.

Kementerian Kesehatan Republik Indonesia. (2013). Profil Kesehatan Indonesia 2012. Jakarta: Kemenkes, RI.

Kementerian Kesehatan Republik Indonesia. (2014). Profil Kesehatan Indonesia 2013. Jakarta: Kemenkes, RI.

Kementerian Kesehatan Republik Indonesia. (2015). Profil Kesehatan Indonesia 2014. Jakarta: Kemenkes, RI.

Kementerian Kesehatan Republik Indonesia. (2016). Profil Kesehatan Indonesia 2015. Jakarta: Kemenkes, RI.

Kementerian Kesehatan Republik Indonesia. (2017). Profil Kesehatan Indonesia 2016. Jakarta: Kemenkes, RI.

McCullagh, P., \& Nelder, J. (1989). Generalized Linear Models (2 ${ }^{\text {nd }}$ ed). London: Chapman and Hall.

Nandasari, B.N. \& Wulandari, S.P. (2014). Pemodelan Jumlah Kejadian Luar Biasa Difteri di Jawa Timur Menggunakan Geographically Weighted Negative Binomial Regression (GWNBR). Surabaya: Institut Teknologi Sepuluh November.

Noor, N.N. (2008). Epidemiologi. Jakarta: PT Rineka Cipta.

Smith, D.F. (2008). Diphtheria. In J.P. Byrne (Ed.), Encyclopedia of Pestilence, Pandemics, and Plagues (Vol. 1, pp. 158-161). Westport, CT: Greenwood Press.

World Health Organization. (2016). Increased immunization coverage addresses the equity gap in Nepal. Bulletin of the World Health Organization 2017; 95:261-269.

World Health Organization. (31 Juli 2017). Diphtheria Reported Cases. Diakses pada tanggal 18 Januari 2018 melalui:

http://apps.who.int/immunization_monitoring/globalsummary/timeseries/tsincidenc ediphtheria.html

Yosephine, P. (2017). Kebijakan Program Imunisasi Terkait Penanggulangan KLB Difteri. Jakarta: Kemenkes, RI. 